Article

\title{
An Old Couple in a New Setting: Franco-German Leadership in the Post-Brexit EU
}

\author{
Ulrich Krotz * and Lucas Schramm \\ European University Institute, I-50014 San Domenico di Fiesole, Italy; E-Mails: ulrich.krotz@eui.eu (U.K), \\ lucas.schramm@eui.eu (L.S.) \\ * Corresponding author
}

Submitted: 12 September 2020 | Accepted: 24 October 2020 | Published: 27 January 2021

\begin{abstract}
What are the implications of Brexit for the nature, role, and potential of Franco-German leadership in the EU? Brexit, we contend, is both an expression and a further cause of two broader underlying developments in the contemporary EU: First, a stronger and more prominent German part and position, and second, disintegrative tendencies in several EU policy fields and the EU polity as a whole. This, in turn, has major implications for Franco-German bilateralism and for Franco-German leadership in the EU. In light of a stronger Germany, a relatively weaker France, and significant centrifugal forces, the two largest EU member states must not only realign their bilateral relationship but must also act as a stabilizer in and for the EU. We show that during the EU's recent crises, not least during the Brexit negotiations and the recovery from the Covid-19 pandemic, France and Germany did exercise joint leadership. We also show, however, that major discrepancies persist between the two countries in particular policy fields and with regard to longer-term European objectives. Brexit, with its numerous calamities and implications, thus once again moves Franco-German leadership-and its shortcomings-to center stage in Europe. When it comes to leadership in the EU, there remains no viable alternative to the Franco-German duo. Yet, in order to provide constructive leadership and successfully shape the EU, the two countries must bridge substantial differences and be ready to carry disproportionately high burdens.
\end{abstract}

\section{Keywords}

bilateralism; Brexit; Covid-19; EU; France; Germany; leadership

Issue

This article is part of the issue "What Brexit Means for Europe: EU Institutions and Actors after the British Referendum" edited by Edoardo Bressanelli (Sant'Anna School of Advanced Studies, Italy) and Nicola Chelotti (Loughborough University London, UK).

(C) 2021 by the authors; licensee Cogitatio (Lisbon, Portugal). This article is licensed under a Creative Commons Attribution 4.0 International License (CC BY).

\section{Introduction}

In the early hours of 9 December 2011, British Prime Minister David Cameron famously vetoed a revision of the Treaty of Lisbon, the contractual basis of the EU. France's President Nicolas Sarkozy and Germany's Chancellor Angela Merkel had suggested a new EU-wide treaty to tighten national budgetary discipline in an attempt to salvage the common currency and put an end to the Eurozone crisis. They had not been willing to give in to Cameron's demands for British exemptions and concessions to its financial services sector.
Cameron's veto pleased many policymakers from his Conservative Party and the British Eurosceptic press. Going further, he asserted that if British interests were not served, its membership in the EU was no longer a given (Traynor, Watt, \& Gow, 2011). Little more than a year later, Cameron would hold out the prospect of a British referendum on EU membership, which eventually triggered Brexit. Meanwhile, France and Germany had convinced 25 of the then $27 \mathrm{EU}$ member states to sign a 'fiscal compact' on closer economic and fiscal integration on an intergovernmental basis, bypassing British opposition and leaving the UK further outside the EU's core. 
This episode is one of the last and most prominent examples of Franco-German leadership in the pre-Brexit EU. Since then, the EU has come under pressure in many ways - most notably with the UK: for the first time, a country has withdrawn from EU membership. In this article, we contend that Brexit is both an expression and a further cause of two broader underlying developments in the contemporary EU: First, Germany in recent years has moved to center stage. It plays an ever stronger and more prominent part in EU politics, making German consent indispensable for any agreement at the EU level. And second, disintegrative tendencies in several EU policy fields and the EU polity have put the form and substance of European integration into question. We further argue that this, in turn, has major implications for Franco-German bilateralism and Franco-German leadership in the EU. In light of a stronger Germany, a relatively weaker France, and significant centrifugal forces, the two largest EU member states must not only realign their bilateral relationship but must also act as a stabilizer in and for the EU.

In this article, we take on two tasks. First, we show that in moments of existential crisis in recent years, France and Germany did exercise joint leadership. When the EU as a polity and the future of European integration were at concrete risk, the two countries stuck together, managed to reconcile their national preferences and interests, and led the way toward a common European response to the pressing challenge. We illustrate this by examining France and Germany's role during the Brexit negotiations and the Covid-19 pandemic. Second, however, we also show that major discrepancies persist between the two countries in particular policy fields and with regard to longer-term European objectives. When one partner is more negatively affected by specific developments or policies than the other, and when a joint role and response to a challenge appear less urgent, Franco-German leadership is less likely to materialize and to have a significant impact on EU politics. The Eurozone reform discussions, EU defense policy, and EU asylum and migration policy exemplify this.

We scrutinize the role, relevance, and implications of European political leadership both with regard to different policy fields and challenges, and within the Franco-German duo itself. Our cases represent important instances of European integration and EU politics in recent years. Comparing various crises and challenges, this article holds that explaining important variation in integration outcomes requires consideration of different degrees of Franco-German leadership. The different outcomes show us when, why, and how Franco-German leadership is likely to emerge and engender impact in post-Brexit EU politics. We ground our analysis in primary sources including official member state and EU documents, newspaper reports, and the wider academic literature on political leadership, Franco-German bilateralism, and EU crisis politics. Importantly, absent a more determined Franco-German leadership and, in particu- lar, a more courageous German part, the EU risks yet more muddling through or stalling. We conclude by arguing that when it comes to leadership in the EU, there remains no viable alternative to the Franco-German duo. This alone, however, will not be enough given the various challenges and uncertainties the EU is facing.

\section{Franco-German Leadership in the EU}

Political leadership is an often invoked but also controversial and contested concept, not least in the context of European integration. European integration-that is, the process after the Second World War of European nation states working together ever more closely in political and economic affairs and increasingly pooling their sovereignty at the European level-was in essence an "anti-hegemonic construction" that sought to diffuse and share power between the different actors and put an end to the disastrous balance-of-power politics in Europe (Schild, 2010, p. 1370). At the same time, however, leadership is often necessary to give guidance, overcome collective action problems, and provide stability to a political system-particularly during moments of uncertainty or accelerated change. Leadership can also help, in 'normal' (non-crisis) times, to sound out common ground for reforms and progress on particular political issues.

Due to its anti-hegemonic character, permanent political leadership in the EU by a single member state would meet major resistance and hence is unlikely. In the history of European integration, France and Germany have therefore jointly assumed the leadership role on numerous occasions. The original purpose of European integration was also a response to the decades-long antagonism, struggle for supremacy, and war between these two countries (Krotz, 2014). As founding members of today's EU, French and German political elites feel a special responsibility to preserve and foster the peaceful political and economic unification of Europe. They can thereby draw on a unique set of political, administrative, and public ties. Indeed, today's Franco-German "embedded bilateralism" is the most institutionalized form of member state cooperation within a regional political organization (Krotz \& Schild, 2013).

Moreover, France and Germany are the two biggest countries in the EU which often have available the necessary political, material, institutional, and idealist resources to provide leadership. A recent survey amongst politicians and experts has confirmed that Germany and France (in this order) are the most contacted and most influential EU countries (Busse et al., 2020). Generally, leadership is possible when there is demand for it amongst political actors, and when a single actor or small group of actors is able and willing to supply it. Leadership demand might result from increased status quo costs for member states, while leadership supply depends on the leader's expected costs and benefits of leading. Leadership in and of the EU tends to be successful and to have a real impact when the leader(s) 
manage to reconcile their own preferences and interests with those of their followers and to enable the achievement of common objectives (Schoeller, 2019, pp. 28-40).

Franco-German bilateralism and its impact on EU politics comprises three main types of leadership: the promotion of further European integration; closer cooperation and forms of differentiated integration; and crisis management and the overcoming of decision-making deadlocks. France and Germany may exercise such leadership in three main ways: (1) setting the political agenda, either by submitting their own proposals or by removing competing proposals from the agenda; (2) building consensus and brokering compromises between themselves and then between different camps of member states; (3) and wielding coalitions of like-minded member states, especially in situations in which large majorities are necessary for an agreement. They then can overrule opposition and sideline reluctant members, as was the case with David Cameron in the run-up to the fiscal compact (Krotz \& Schild, 2013, pp. 20-22).

In recent years, Franco-German leadership in the EU has become at once more challenging and more essential (Krotz \& Maher, 2016). On the one hand, after various enlargement rounds, we see a larger and more heterogeneous EU in terms of political culture, economic interests, and national policy preferences. More importantly for Franco-German leadership, Germany has occupied a more prominent and at times dominant position. Especially during the global financial and subsequent Eurozone crises, but also during the Covid-19 pandemic, Germany's superior economic and fiscal position revealed a growing asymmetry within the Franco-German duo. Germany, it seems, has become the "indispensable nation" for any agreement on the EU level (Sikorski, 2011). France, by contrast, has struggled for years with slow or no economic growth as well as political and social divisions and protests that have challenged its entire political system. What is more, the anti-EU National Rally (formerly Front National)-the largest political force in France in the 2019 European parliamentary elections-promotes more nationalist positions and makes negotiating successes at the EU level all the more important for the French president (Bulmer \& Paterson, 2019, p. 13).

On the other hand, various centrifugal forces and disintegrative tendencies have rattled selected policy fields and even the entire EU polity. Brexit, of course, is the single most obvious embodiment of this development. That a country has for the first time opted to withdraw from EU membership led some scholars to speak of a "European disintegration" (Webber, 2019, pp. 19-30; see also Schramm, 2020). In the immediate aftermath of the referendum, some scholars speculated that Brexit could create and further increase the incentives for other member states to follow the British example and withdraw from the EU membership. In any event, Brexit has once again moved Franco-German leadership into focus, since it increases the visibility and relative impor- tance of the two remaining large member states (Krotz \& Schild, 2018).

But the EU has seen other disintegrative tendencies as well. During the Eurozone crisis from 2010 to 2015, the common currency came under severe pressure, revealing the shortcomings in its institutional design and pushing some member states to the edge of exit. In the migration crisis of 2015 and 2016, the ongoing clash amongst member states over a quota system and the more equal distribution of refugees led not only to the undermining of common EU decisions but also to the reintroduction of border controls within the Schengen free-traveling area. And the 'Covid-19 summit' of July 2020 revealed different and opposing coalitions of Northern, Southern and Eastern member states, which were in severe dispute over the size, allocation, and governance structure of a European economic recovery fund.

After the election of the pro-European Emmanuel Macron as President of France in May 2017, there were high expectations that France, together with Germany, could lead the way to a much-needed reform and impetus for the EU. In a speech at the Sorbonne University in September 2017, Macron called, among other things, for a separate budget to make the Eurozone more robust and for more integration in defense and security to transform the EU into a true political player on the global stage (French Presidency, 2017). Despite some occasional rhetorical expressions of support and the public and symbolic cultivation of the Franco-German relationship (Krotz, 2002), the new German government, which took office in March 2018, never really engaged with the Macron proposals. This, however, contrasts the prominent role that France and Germany played in the management of both the Brexit and the Covid-19 crises. In both cases, the two countries assumed joint leadership, seeking to keep the EU member states together and showing ways to deal with the pressing challenges.

In order to explain this variation and document the distinctive role of France and Germany, we put forward a framework that deviates from and extends beyond many of the main theories of European integration (see also Krotz \& Schild, 2013, pp. 11-16). These existing theories often focus primarily on general trends and outcomes in integration but tend to say little about the precise forms and mechanisms of European decision-making and crisis management at particular moments in time. In contrast to both neo-functionalism (Haas, 1958) and multi-level governance approaches (Marks, Hooghe, \& Blank, 1996), we attribute a more prominent part to two large EU member states. This focus also helps us to better account for enabling or constraining factors for European cooperation and integration, which might stem both from the respective domestic environments in these two countries and from their bilateral relationship.

Concentrating on two key states, our theorizing obviously connects to intergovernmentalism, which holds true both for its classic formulation and Stanley Hoffmann's (1966) emphasis on the differences between 
national structures and cultures, and for Andrew Moravcsik's (1998) liberal mode and the process of domestic preference formation. At the same time, we go beyond these intergovernmentalisms in that we stress political agency and strategizing and Franco-German influence (or the lack thereof), both in concrete moments (of crisis) and in the evolution of specific EU policy fields. Lastly, we deviate from accounts of German hegemony in the EU (Bulmer \& Paterson, 2019) in that we also look at policy fields in which German influence is less pronounced and at instances in which Germany was able to shape EU politics only in partnership with France.

\section{Brexit}

After his announcement of an in/out referendum on British EU membership in January 2013 and his electoral success in the UK parliamentary elections in June 2015, Prime Minister Cameron reinforced his demands for a new settlement and a renewed British position within the EU. In the run-up to the Brexit referendum, Cameron from summer 2015 onwards conducted negotiations with the EU's other heads of state or government. He in particular asked for a formal exemption of the UK from the goal, anchored in the preamble to the EU Treaties, to strive for an 'ever closer Union' and for the right to restrict the free movement of people within the EU in order to reduce the number of EU migrants coming to the UK.

The declared objective of the other member states was to avert 'Brexit' and to compel the UK to stay in the EU. According to some observers, Cameron hoped that German Chancellor Merkel in particular would manage to broker generous provisions on behalf of the EU, given her prominent position amongst the European leaders and the supposedly very major interest of German politics and industry in keeping the UK within the EU at any cost (Webber, 2019, pp. 177-206). However, for the other member states, there were limits on how far they were willing to accommodate. As Merkel stressed in October 2015, for her the free movement of people in the EU was non-negotiable. Similarly, France's then-President François Hollande ruled out a timely change to the EU Treaties to meet Cameron's demands, not least since opening the Treaties could have triggered a French referendum with an uncertain outcome (Traynor, 2015).

In their European Council Conclusions of 18 and 19 February 2016, the heads of state or government stressed the UK's special status in the EU and promised legal changes in the case of a Remain vote. Most notably, they exempted the UK from 'ever closer Union.' In contrast, however, the heads did not alter the principle of the free movement of people. The UK would be given the right to restrict benefits for new migrants for four years, but it would not have the right to suspend intra-EU migration. In addition, the Conclusions did not entail a concrete date or formal provisions for a Treaty change to implement the agreed upon changes (European Council, 2016a).
After the June 2016 referendum and during the exit negotiations with the UK, the other EU member states were keen to keep and foster the unity of the EU-27 and to minimize the incentives for further withdrawals. Less than three months after the Brexit referendum, in their Bratislava Declaration of 16 September 2016, the heads of state or government stressed that despite the UK's decision to leave, "the EU remains indispensable for the rest of us"; they were "determined to make a success of the EU with 27 Member States" (European Council, 2016b). At that meeting, they also endorsed the 'Bratislava Roadmap,' a work program for the coming months to tackle pressing challenges such as migration, external security, and economic development (European Council, 2016b).

Starting on 1 October 2016, the EU-27 entrusted the formal conduct of the exit negotiations to the European Commission and the European Council and their newly created Brexit task forces (Laffan, 2019). On various occasions, France and Germany acknowledged the importance of a future close relationship between the EU and the UK, particularly in security, defense, and intelligence policies. At the same time, however, they stressed the integrity of the European single market with its four freedoms (of people, labor, goods, and capital) and excluded any special provisions for the UK. Speaking to the German Bundestag on 28 June 2016, five days after the Brexit referendum, Chancellor Merkel excluded "cherry-picking" when it came to access to the single market and argued that as a future third country the UK must not enjoy the same rights and privileges as it did as an EU member. Moreover, Merkel ruled out separate, bilateral negotiations between a single member state and the UK government ("Merkel zum Brexit," 2016).

France and Germany were determined to prevent Brexit from becoming a success story, to highlight the benefits of EU membership, and to avoid further European rupture and disintegration. The new French President Macron took a particularly tough stance on the UK. In October 2019, he initially objected to a second Brexit extension and urged the EU-27 to move on to final British withdrawal (Rankin \& Boffey, 2019). Overall, the negotiations with the UK both before and after the Brexit referendum have shown that Germany and France, as the UK's first and third largest trading partners, preferred a smaller but still highly integrated EU to a larger EU that could include the UK but would then be less integrated. The stance of France and Germany and their commitment to a highly integrated EU were crucial to the unity of the EU-27 and to preventing other member states seeking to follow the British example of withdrawing from EU membership.

\section{Covid-19}

Beginning in early March 2020, Covid-19 spread rapidly across EU member states, forcing governments to impose tough constraints on individual outdoor and 
economic activities, as well as severe travel restrictions even within the putative open-border Schengen area. The Covid-19 lockdown led to an unprecedented decline in member states' economic output, increased unemployment, rising expenditures for public health, and rising government debt levels. As it became clear, member states were differently prepared to cope with the costs or to initiate economic recovery. While Northern EU countries including Germany generally had rather sound public finances and thus considerable fiscal leeway to provide national stimulus programs, Southern EU countries such as Italy and Spain, but also France, had significantly fewer available resources.

At the European Council meeting on 26 March 2020, the EU's heads of state or government articulated the "unprecedented challenge" of the Covid-19 pandemic and called for Eurozone finance ministers to present proposals for a decisive common economic and fiscal response (European Council, 2020a). However, there were major discrepancies between member states about the adequate financing and allocation of a European fiscal support package. On one side, France joined a group of eight other EU countries calling for the introduction of 'Covid-19 bonds' (the joint issuance and liability of government debt) and support in the form of non-repayable grants (Dombey, Chazan, \& Brunsden, 2020).On the other side, Germany, together with other Northern EU countries like Austria and the Netherlands, rejected Covid-19 bonds and insisted on the allocation of credits from the European Stability Mechanism, the Eurozone's permanent bailout fund, to the hardesthit countries. On 23 April 2020, the European Council endorsed an initial European fiscal support package worth $€ 540$ billion, consisting largely of credits from the European Stability Mechanism. At the same time, the heads of state or government indicated that they deemed this first support package alone insufficient and called upon the European Commission to present a timely proposal for a European recovery fund (Council of the EU, 2020).

Surprisingly for many, Macron and Merkel on 18 May 2020 presented a joint proposal for a temporary recovery fund to be linked with the EU's next multiannual budget. According to the Franco-German plan, the Commission, on behalf of and backed by the member states, would raise $€ 500$ billion on the financial markets, which would then be distributed to the worstaffected EU regions via grants (Bundeskanzlerin, 2020). Politicians and analysts called the Franco-German plan a potential turning point in the history of the EU, since it would for the first time allow the Commission to borrow money on such a scale. Some observers went as far as to argue that the Franco-German initiative marked a big step toward a European fiscal union and the EU's "Hamiltonian moment," in reference to Alexander Hamilton, the first treasurer of the US who summarized the regions' debt levels and issued new debt on behalf of the federal government (Kaletsky, 2020).
The move towards common EU debt indeed marked a remarkable deviation from the traditional German stance, as did the proposal to distribute fiscal support entirely in the form of grants rather than credits. So far, Germany had opposed greater fiscal burden-sharing at the EU level and the transfer of fiscal resources to Europe's poorer and most crisis-ridden regions. At the same time, the plan also deviated from the former French position in that the recovery fund would not be financed through a new and timely unlimited EU instrument, such as Covid-19 bonds. Instead, this would be a one-time tool tied to the EU's regular budget, with all the associated oversight in terms of spending priorities and economic reform efforts. Both France and Germany thus had moved away from their former Southern and Northern camps of supposedly like-minded countries and shifted into the role of mediators, forging a bilateral plan which could then serve as the blueprint for a broader European comprise.

On 27 May, in the wake of the Franco-German initiative, the Commission presented its much-anticipated proposal for a second European fiscal support package, which essentially consisted of two elements: first, a European recovery instrument called 'Next Generation EU' and worth $€ 750$ billion, to be financed by Commission borrowing and composed of almost twothirds in grants and the rest in loans and guarantees; and second, a renewed proposal for the EU's next multi-annual budget totaling $€ 1,1$ trillion, to be agreed upon by member states by the end of 2020, with increased EU-spending on Covid-19-related issues (European Commission, 2020). The Commission thus largely adopted the size and financing rationale of the Franco-German plan, while it added another $€ 250$ billion in the form of credits.

When presenting the plan to the press on 18 May, President Macron, not without pride, stated that "an agreement between Germany and France is not an agreement of the 27 [EU member states], but there can be no agreement among the 27 if there is not already a FrancoGerman agreement" (Fleming, Mallet, \& Chazan, 2020). The heads of state or government endorsed the European recovery fund, together with the EU's next multi-annual budget, at the four-day European Council summit in July (European Council, 2020b). In the run-up to that summit, Merkel and Macron both in bilateral gatherings and in several separate meetings with other national leaders explored common ground and options for compromises. According to two close observers, throughout the summit itself, Merkel and Macron were careful to follow a common line, insisting on an agreement among the 27 member states (Gutschker \& Wiegel, 2020).

\section{Between Short-Term Crisis Management and Longer-Term European Objectives}

In view of existential threats to the EU and the future of European integration-such as Brexit and the Covid-19 
crisis-France and Germany thus have repeatedly exercised decisive European leadership. Keen to maintain and further strengthen the unity of the EU-27, both countries set aside narrowly conceived national and economic self-interests during the Brexit negotiations. During the Covid-19 crisis, France and Germany paved the way for a common and comprehensive European fiscal support package. Initially, the two countries had represented different camps, with France aligning with mostly Southern EU countries to call for the introduction of Covid-19 bonds while Germany sided with other Northern countries and insisted on the allocation of credits only. In their joint proposal for an EU recovery fund, however, each deviated from its original stance. The Franco-German initiative formed the blueprint and necessary political backing for the following Commission proposal and, eventually, the agreement of the 27 member states on the EU's response to the Covid-19 crisis. In terms of leadership, it is an example of both agenda-setting and consensusbuilding in order to overcome impasse amongst member states, prevent the Covid-19 crisis from further escalating, and start Europe's economic recovery.

At the same time, and apart from acute EU crisis management, France and Germany have also refrained repeatedly from assuming-or even failed to exercisepolitical leadership. With regard to longer-term EU reforms and objectives, we see some deep and fundamental discrepancies between France and Germany, and among EU member states at large: Beyond the immediate reforms in the course and aftermath of the Eurozone crisis, the future performance and resilience of Europe's monetary union remain uncertain. Shifts in global security, and in transatlantic relations in particular, call for a reorientation in European security and defense policy. Moreover, the ongoing disputes about the reception and relocation of refugees and the safeguarding of the EU's external borders threaten the functioning of the European asylum system and, as a consequence, the Schengen free-travelling area. In the following, we explore each of these discrepancies in some more detail.

In his programmatic Sorbonne speech on the future of Europe in September 2017, Macron called for a "sovereign, united and democratic Europe." Specifically, he promoted more efforts and investments in the autonomous defense of Europe and the creation of "a common strategic culture," "a common intervention force," and "a common defense budget." He further demanded a "common budget" for the Eurozone in order to finance joint projects, cushion economic shocks, and reduce economic imbalances within the Eurozone (French Presidency, 2017). In that speech, delivered just two days after the 2017 parliamentary elections in Germany, Macron offered Chancellor Merkel and the future German government "a new partnership" and a privileged Franco-German role in the implementation of these projects. And when awarded the prestigious Charlemagne Prize for European unity in the German city of Aachen in May 2018, Macron further elaborated on his long-term goals for the EU. Repeating his calls for a Eurozone budget, Macron explicitly called on Germany to get over its "fetish" for budget surpluses and work with him on forging deeper European economic integration (“Macron's EU," 2018).

The German government, however, reacted remarkably passively to Macron's advances. It was only in March 2019 that Annegret Kramp-Karrenbauer, Merkel's successor as party leader of the Christian Democratic Union, presented her suggestions for the future of the EU, which were largely interpreted as a response to Macron. Regarding monetary union, Kramp-Karrenbauer did not mention the possibility of further integration but instead called for more "subsidiarity" and member state "responsibility" (Mühlherr, Schiltz, \& Schuster, 2019). Further, she caused opposition and open outrage in Paris by suggesting that France, if it seeks a more effective EU, should give up its permanent seat in the United Nations' Security Council in favor of a European seat and should sacrifice the part-time base of the European Parliament in Strasbourg ("A conservative German response," 2019).

This belated and half-hearted response reinforced the image of a Germany that is quite satisfied with the status quo in Europe, especially when it comes to economic and fiscal policies. Indeed, a survey conducted at the same time that Macron received the Charlemagne prize showed that half of German voters thought his proposals for economic and financial integration went "too far" ("Emmanuel Macron receives Charlemagne Prize," 2018). Only a few weeks later, more than 150 German economists signed an open letter denouncing Macron's proposals and calling for national economic reforms instead of disincentives and a European transfer union (Plickert \& Mussler, 2019). Not surprisingly, thus, the German government-despite having formally approved France's call for a Eurozone budget in their Meseberg declaration of June 2018-showed little enthusiasm to seriously push the project forward, and it put up little resistance when several smaller Northern EU countries substantively watered down the Eurozone budget in the following months (Schoeller, 2020). Together, these episodes illustrate that the German government shies away from a profound reform and further development of the Eurozone, fearing the joint liability for banks and government debt, permanent fiscal transfers from Europe's North to its South, and a backlash from its electoral base.

Regarding European defense, Chancellor Merkel had already stated in May 2017 that the times in which Europe "could fully rely on others" were over, asserting that "we Europeans must really take our fate into our own hands" ("Kanzlerin trotzt Trump," 2017). She primarily referred to the US' questioning of multilateral fora and alliances such as NATO under President Donald Trump, but also to Brexit ("Kanzlerin trotzt Trump," 2017). On 11 December 2017, 25 EU member states agreed to intensify their defense cooperation within the framework of the Permanent Structured Cooperation. Due to the 
legally binding commitments of the member states, the Permanent Structured Cooperation is the most advanced form of defense cooperation in the EU. Together with the European Defense Fund, established in June 2017 in an effort to coordinate national investment in defense research, the Permanent Structured Cooperation was also a response to Brexit and the UK's withdrawal from the EU defense framework.

Germany's supposedly more confident and vigorous approach towards European security and defense should meet France's ambitions and stances in this policy field. Indeed, the European Intervention Initiative, which Macron had also mentioned in his Sorbonne speech, was officially formed in June 2018. In establishing military cooperation between at first eight EU member states and the UK outside the existing structures of NATO, it could represent a significant step towards European 'strategic autonomy.' Yet, the precise details, competences, and resources of such novel alliances and initiatives-and hence the future of European security and the prospect of a proper European defense policyremain largely unclear. Despite its otherwise broad ambitions, the Franco-German Treaty of Aachen from January 2019 in security and defense does not go beyond bilateral consultations between the two countries, stopping short of pooling resources and joint decision-making procedures (Seidendorf, 2019, pp. 198-200). It still holds that security and defense remain the last bastions of national sovereignty, including for these two countries. Also, while France has long promoted greater European defense autonomy, Germany has traditionally insisted on a key role for NATO and a close partnership with the US (Krotz \& Sperling, 2011). To date, the security and defense domains have thus seen only sporadic and often half-hearted Franco-German leadership.

The EU's asylum and migration policy is a third area with rather limited Franco-German leadership over the past years. In 2015 and 2016, the EU faced an unprecedented number of incoming refugees and migrants. The severe disputes over their reception and relocation brought the Common European Asylum System to the brink of collapse, while the partial reintroduction of national border controls to contain the migratory flows threatened the principle of free travel inside the Schengen area. Germany, which received the most asylum applications, sought to establish a refugee quota at the EU level. Although France also advocated a more equal distribution, President Hollande and his government were much more reluctant to institute a permanent and legally binding quota system. When Germany, together with the European Commission, in March 2016 negotiated and concluded a political deal with Turkey to lower the migratory flows to Europe, France hardly played a role. Since then, either bilaterally or in a small group of member states, France and Germany have repeatedly advocated a new European asylum policy and more intra-European burden-sharing. In September 2019 , for example, the interior ministers of both coun- tries, together with those from Italy and Malta, agreed on the internal relocation of rescued refugees from the Mediterranean Sea (“EU ministers in Malta," 2019).

Overall, however, France and Germany have so far not succeeded in putting the EU's asylum and migration policy and the Common European Asylum System on a more sustainable, reliable, and crisis-proof footing. This is also because the two countries themselves often do not agree on the next steps, as became apparent with the mandatory quota system. In other instances, France and Germany announced possible measures but then did not pursue them credibly and in the longer term: Both the German Interior Minister Thomas de Maizière (in September 2015) and President Macron (in April 2019) raised the option of excluding member states that overtly oppose the relocation of asylum-seekers and other contributions to a common EU asylum policy from the Schengen area. Yet, so far, the two countries have backed away from proceeding in sub-groups of likeminded member states and from engaging in forms of differentiated integration.

Beyond these specific policy fields and challenges, France and Germany are aware of their special bilateral relationship and their historical responsibility for the European integration project. This they have repeatedly expressed, not least in the context of Brexit. In the Meseberg declaration of 19 June 2018, both countries expressed their determination to "further strengthen their cooperation within the European Union" and at the same time "to ensure the unity of the member states and the performance of the Union" (Bundesregierung, 2018). And in the Treaty of Aachen on 22 January 2019, an extension of the Franco-German 'Elysée' friendship treaty from 1963, both agreed to take their bilateral cooperation to a new level, for example by further aligning their economic, social, and tax systems and by creating new instruments for cross-border cooperation (France Diplomacy, 2019).

As the previous sections have shown, however, we thus often see a gap between Franco-German leadership in moments of acute threat to the EU, on the one hand, and their role with regard to longer-term objectives and more fundamental reforms in the EU-as well as the commitments and symbolic gestures of the two countries-on the other hand. Regarding the current political leaders and elites in the two countries, we also see differences in personal traits, ways of policymaking, and visions for the future of the EU. President Macron on various occasions called for prompt and largescale changes and reforms of particular EU policies and the entire EU. These advances, however, led to reservations and sometimes open opposition in German government circles, which see them as premature or even dangerous, and selective in that they seek to strengthen France's position and role in Europe. Conversely, the often pragmatic but also hesitant political style of Chancellor Merkel and other leading German politicians, not least when it comes to greater German commitment 
in European financial and security affairs, has led to frustration in Paris (Drozdiak, 2020, pp. 89-110).

\section{Conclusions}

The UK's decision to leave the EU has once again moved the Franco-German duo to center-stage in Europe. As the two largest and most influential EU member states, France and Germany's joint role and leadership continue to be crucial for the future of Europe, its integration, and the politics of its union. This is even more the case at a time when the EU is facing numerous crises, challenges and disintegrative tendencies, and a growing asymmetry in the Franco-German relationship due to a more dominant and at times complacent German stance, particularly in economic terms. Despite initial difficulties based on partly different preferences and interests, France and Germany, at moments of existential threat for the EU and the European integration process of the past decade, have exercised joint leadership. A Franco-German agreement might not be sufficient for consent at the EU level, but it is a necessary condition for effective crisis management and the overcoming of decision-making deadlocks amongst EU member states. Absent Franco-German leadership, the European project meanders between the poles of uninspired or reluctant German preponderance on the one hand, and yet more muddling through or stalling, on the other.

In the run-up to and the aftermath of the Brexit referendum, France and Germany were keen to preserve the integrity of the European single market, to maintain the unity of the remaining EU countries, and to prevent further member state withdrawals. Their leaders took a hard and unified line against the UK, signaling that as a third country the UK would not enjoy the same benefits as it did as a member state. In the course of the Covid-19 crisis, they set the political agenda and paved the way for a comprehensive European fiscal support package, building a compromise among all member states to tackle the economic damage caused by Covid-19 and to start recovery. In this regard, France and Germany lived up to their special role and historical vocation for European integration, which the political leaders of the two countries so often stress.

By contrast, with regard to reforms and further developments in some specific EU policy fields and longerterm EU objectives, Franco-German leadership was often less visible, sometimes only marginally successful, and at other times even entirely absent. Regarding the Eurozone, Germany has shown little enthusiasm and appetite for major new steps. Discussions and negotiations on the completion of banking union, for example, are stalling, not least due to German reluctance. The large Eurozone budget, called for by Macron to make the Eurozone more stable and crisis-proof, was decisively watered down with the (hidden) consent of Berlin. With regard to EU security and defense, Germany, despite a change in rhetoric, still is rather reluctant when it comes to increasing defense spending and taking part in military interventions. Finally, an overhaul of the EU's asylum and migration system and greater burdensharing among member states in terms of the reception and relocation of asylum-seekers is clearly in Germany's interests and high up on the country's political agenda. In light of half-hearted French support, however, Germany alone has little backing or power to deeply and lastingly reform EU asylum policy. For these longerterm EU undertakings and objectives, thus, France and Germany so far have been either unwilling or unable to exercise joint leadership.

In sum, France and Germany are more likely to supply political leadership in moments of existential crisis and threat when they manage to reconcile their own preferences and interests. In these instances, there also is a higher demand for leadership amongst other member states so that Franco-German influence becomes more legitimate and more likely to be successful, and to have a substantial impact on EU politics. Things are rather different when it comes to more fundamental and longerterm questions regarding particular EU policy fields and the future of European integration. Here, profound differences remain between the two countries' priorities and conceptions of the form, substance, and direction of the EU. In addition, the rhetoric and political style often diverge considerably in the two countries, and between the French President and the German Chancellor in particular, making a common policy stance and initiatives and hence a credible offer of Franco-German leadership difficult.

Are there options that could plausibly replace or supplement Franco-German leadership in the EU in the foreseeable future? Indeed, other subgroups of member states have sometimes joined forces to pursue certain policy objectives. The Visegrád group of four Central and Eastern EU countries fiercely opposed an EU refugee quota system. In EU budget negotiations, these countries are keen to maintain large financial transfers through the EU's structural and cohesion funds. In the aftermath of the Eurozone crisis, the 'New Hanseatic League,' a group of economically liberal and trade-oriented member states, called for a larger role for EU institutions in scrutinizing national budgets and enforcing fiscal discipline. And during the Covid-19 crisis, a subgroup of the Hanse-the 'frugals': Austria, Denmark, Sweden, and the Netherlands, at times with Finland's open or tacit support-have demanded a more limited fiscal support package and pushed for a higher ratio of credits to grants.

These coalitions, however, are more concerned with blocking or moderating (oftentimes far-reaching) proposals at the EU level than with providing credible leadership options. When it comes to creative, constructive, and bridge-building solutions to pressing problems and measures ultimately acceptable to all-or at least to a vast majority of EU member states - there is still no credible alternative to the Franco-German duo. In order to pro- 
vide leadership beyond moments of acute threat to the EU, however, France and Germany must find even more common ground, re-energize their bilateral relationship, and pursue a joint role in EU politics. This may well include cooperating in large subgroups of like-minded member states and moving the EU towards more flexible integration schemes. The EU's recent proposal for a 'New Pact on Asylum and Migration' might be a test case for such an endeavor.

\section{Acknowledgments}

For helpful comments on an earlier version of this article, we thank Edoardo Bressanelli and Nicola Chelotti as well as three anonymous reviewers. We are grateful to Sarah Tarrow for excellent editorial support.

\section{Conflict of Interests}

The authors declare no conflict of interests.

\section{References}

A conservative German response to Macron's EU vision. (2019, March 11). Financial Times. Retrieved from https://www.ft.com/content/2ad3d532-43f8-11e9b168-96a37d002cd3

Bulmer, S., \& Paterson, W. E. (2019). Germany and the European Union: Europe's reluctant hegemon? London: Macmillan.

Bundeskanzlerin. (2020, May 18). A French-German initiative for the European recovery from the Coronavirus crisis [Press release]. Retrieved from https:// www.bundesregierung.de/breg-en/news/dt-franzinitiative- 1753890

Bundesregierung. (2018, June 19). Meseberg declaration: Renewing Europe's promises of security and prosperity [Press release]. Retrieved from https:// archiv.bundesregierung.de/archiv-de/meta/ startseite/meseberg-declaration-1140806

Busse, C., Franke, U., Loss, R., Puglierin, J., Riedel, M., \& Zerka, P. (2020). EU coalition explorer. European Council on Foreign Relations. Retrieved from https:// www.ecfr.eu/eucoalitionexplorer

Council of the EU. (2020, April 23). Conclusions of the President of the European Council following the video conference of the members of the European Council [Press release]. Retrieved from https://www. consilium.europa.eu/en/press/press-releases/2020/ 04/23/conclusions-by-president-charles-michelfollowing-the-video-conference-with-members-ofthe-european-council-on-23-april-2020

Dombey, D., Chazan, G., \& Brunsden, J. (2020, March 25). Nine eurozone countries issue call for 'coronabonds.' Financial Times. Retrieved from https:// www.ft.com/content/258308f6-6e94-11ea-89df41 bea055720b

Drozdiak, W. (2020). The last president of Europe:
Emmanuel Macron's race to revive France and save the world. New York, NY: Public Affairs.

Emmanuel Macron receives Charlemagne Prize for European unity in Aachen. (2018, May 10). Deutsche Welle. Retrieved from https://www.dw.com/en/ emmanuel-macron-receives-charlemagne-prizefor-european-unity-in-aachen/a-43727296

EU ministers in Malta to thrash out new migrant system. (2019, September 23). Euractiv. Retrieved from https://www.euractiv.com/section/justice-homeaffairs/news/eu-ministers-in-malta-to-thrash-outnew-migrant-system

European Commission. (2020, May 27). Europe's moment: Repair and prepare for the next generation [Press release]. Retrieved from https://ec. europa.eu/commission/presscorner/detail/en/ ip_20_940

European Council. (2016a). European Council meeting (18 and 19 February 2016): Conclusions. Brussels: European Council. Retrieved from https://www. consilium.europa.eu/media/21787/0216-eucoconclusions.pdf

European Council. (2016b). Bratislava declaration and roadmap. European Council. Retrieved from https:// www.consilium.europa.eu/en/policies/eu-futurereflection/bratislava-declaration-and-roadmap

European Council. (2020a). Joint statement of the members of the European Council. Brussels: European Council. Retrieved from https://www.consilium. europa.eu/media/43076/26-vc-euco-statementen.pdf

European Council. (2020b). Special meeting of the European Council (17, 18, 19, 20 and 21 July 2020): Conclusions. Brussels: European Council. Retrieved from https://www.consilium.europa.eu/media/45109/ 210720-euco-final-conclusions-en.pdf

Fleming, S., Mallet, V., \& Chazan, G. (2020, May 18). Germany and France unite in call for $€ 500$ bn Europe recovery fund. Financial Times. Retrieved from https://www.ft.com/content/c23ebc5e-cbf3-4ad885aa-032b574d0562

France Diplomacy. (2019). Franco-German treaty of Aachen. France Diplomacy. Retrieved from https:// www.diplomatie.gouv.fr/en/country-files/germany/ france-and-germany/franco-german-treaty-ofaachen

French Presidency. (2017). Discours d'Emmanuel Macron pour une Europe souveraine, unie, démocratique [Emmanuel Macron's speech for a sovereign, united, democratic Europe]. Paris: Élysée Palace. Retrieved from https://www.elysee.fr/front/pdf/ elysee-module-795-fr.pdf

Gutschker, T., \& Wiegel, M. (2020, July 22). EU-Gipfel: Wie Merkel und Macron Rutte und Orbán in die Schranken wiesen [EU summit: How Merkel and Macron put Rutte and Orbán in their place]. Frankfurter Allgemeine Zeitung. Retrieved from https:// www.faz.net/aktuell/politik/ausland/wie-merkel- 
und-macron-viktor-orban-austricksten-

16872301.html

Haas, E. B. (1958). The uniting of Europe: Political, social and economic factors, 1950-57. London: Stevens \& Sons.

Hoffmann, S. (1966). Obstinate or obsolete? The fate of the nation-state and the case of Western Europe. Daedalus, 95(3), 862-915.

Kaletsky, A. (2020, May 21). Europe's Hamiltonian Moment. Project Syndicate. Retrieved from https:// www.project-syndicate.org/commentary/frenchgerman-european-recovery-plan-proposal-byanatole-kaletsky-2020-05?barrier=accesspaylog

Kanzlerin trotzt Trump: "Wir müssen unser Schicksal wirklich in die eigene Hand nehmen" [Chancellor defies Trump: "We really have to take our fate into our own hands"]. (2017, May 28). Frankfurter Allgemeine Zeitung. Retrieved from https://www.faz. net/aktuell/politik/angela-merkel-zweifelt-anzuverlaessigkeit-von-donald-trump-15036287.html

Krotz, U. (2002). Social content of the international sphere: Symbols and meaning in Franco-German relations (Working Paper No. 02.2). Cambridge, MA: Minda de Gunzburg Center for European Studies.

Krotz, U. (2014). Three eras and possible futures: A longterm view on the Franco-German relationship a century after the First World War. International Affairs, 90(2), 337-350.

Krotz, U., \& Maher, R. (2016). Europe's crises and the EU's 'big three.' West European Politics, 39(5), 1053-1072.

Krotz, U., \& Schild, J. (2013). Shaping Europe: France, Germany, and embedded bilateralism from the Elysée treaty to twenty-first century politics. Oxford: Oxford University Press.

Krotz, U., \& Schild, J. (2018). Back to the future? FrancoGerman bilateralism in Europe's post-Brexit union. Journal of European Public Policy, 25(8), 1174-1193.

Krotz, U., \& Sperling, J. (2011). The European security order between American hegemony and French independence. European Security, 20(3), 305-335.

Laffan, B. (2019). How the EU27 came to be. Journal of Common Market Studies, 57, 13-27.

Macron's EU: Most Germans support reforms...to a point. (2018, May 9). Deutsche Welle. Retrieved from https://www.dw.com/en/macrons-eu-mostgermans-support-reforms-to-a-point/a-43726305

Marks, G., Hooghe, L., \& Blank, K. (1996). European Integration from the 1980s: State-centric v. Multi-level governance. Journal of Common Market Studies, 34(3), 341-378.

Merkel zum Brexit: Keine Vorverhandlungen, keine Rosinenpickerei [Merkel on Brexit: No preliminary negotiations, no cherry-picking]. (2016, June 28). Der Spiegel. Retrieved from https://www.spiegel.de/ politik/deutschland/regierungserklaerung-vonangela-merkel-keine-vorverhandlungen-keinerosinenpickerei-beim-brexit-a-1100148.html
Moravcsik, A. (1998). The choice for Europe: Social purpose and state power from Messina to Maastricht. Ithaca, NY: Cornell University Press.

Mühlherr, S., Schiltz, C., \& Schuster, J. (2019, March 9). Kramp-Karrenbauer gibt die deutsche Antwort auf Macron [Kramp-Karrenbauer gives the German answer to Macron]. Die Welt. Retrieved from https://www.welt.de/politik/deutschland/ article190046303/Europa-richtig-machen-KrampKarrenbauers-deutsche-Antwort-auf-Macron.html

Plickert, P., \& Mussler, W. (2019, May 21). Ökonomen warnen vor Euro-Haftungsunion [Economists warn against euro liability union]. Frankfurter Allgemeine Zeitung. Retrieved from https://www.faz.net/ aktuell/wirtschaft/konjunktur/oekonomen-warnenvor-euro-haftungsunion-15600643.html

Rankin, J., \& Boffey, D. (2019, October 18). Macron against Brexit extension as Merkel keeps option open. The Guardian. Retrieved from https://www. theguardian.com/politics/2019/oct/18/brexitextension-unavoidable-if-mps-reject-deal-saysmerkel

Schild, J. (2010). Mission impossible: The potential for Franco-German leadership in the enlarged EU. Journal of Common Market Studies, 48(5), 1367-1390.

Schoeller, M. G. (2019). Leadership in the Eurozone: The role of Germany and EU institutions. London: Palgrave Macmillan.

Schoeller, M. G. (2020). Preventing the eurozone budget: Issue replacement and small state influence in EMU. Journal of European Public Policy. https://doi.org/ 10.1080/13501763.2020.1795226

Schramm, L. (2020). Exit from joint-decision problems? Integration and disintegration in the EU's recent polycrisis. European Review of International Studies, 7(1), 2-27.

Seidendorf, S. (2019). Frankreich, Deutschland und die europäische Integration im Aachener Vertrag [France, Germany and European integration in the Aachen Treaty]. Integration, 42(3), 187-204.

Sikorski, R. (2011, November 28). I fear Germany's power less than her inactivity. Financial Times. Retrieved from https://www.ft.com/content/b753cb42-19b311e1-ba5d-00144feabdc0

Traynor, I. (2015, October 18). So what does Europe really think about the Brexit debate? The Guardian. Retrieved from https://www.theguardian.com/ global/2015/oct/18/brexit-what-european-leadersthink-merkel-hollande

Traynor, I., Watt, N., \& Gow, D. (2011, December 9). David Cameron blocks EU treaty with veto, casting Britain adrift in Europe. The Guardian. Retrieved from https://www.theguardian.com/world/2011/ dec/09/david-cameron-blocks-eu-treaty

Webber, D. (2019). European disintegration? The politics of crisis in the European Union. London: Macmillan. 


\section{COGITATIO}

\section{About the Authors}

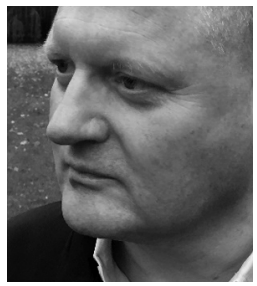

Ulrich Krotz is Professor and Director of the Europe in the World Research Programme at the Robert Schuman Centre for Advanced Studies at the European University Institute. He is the author of Shaping Europe: France, Germany, and Embedded Bilateralism from the Elysée Treaty to Twenty-First Century Politics (with Joachim Schild), History and Foreign Policy in France and Germany, and Flying Tiger: International Relations Theory and the Politics of Advanced Weapons, as well as numerous articles on European affairs and international politics.

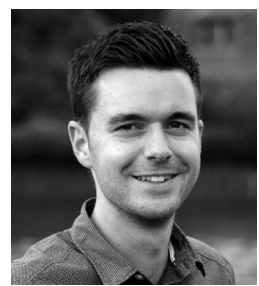

Lucas Schramm is a PhD Researcher at the European University Institute. He holds a MA degree in European Political and Administrative Studies from the College of Europe in Bruges. In his dissertation, he analyzes past and more recent political crises in the process of European integration, seeking to explain the variation in crisis outcomes. His recent publications include "Exit from JointDecision Problems? Integration and Disintegration in the EU's Recent Poly-Crisis" (European Review of International Studies). 